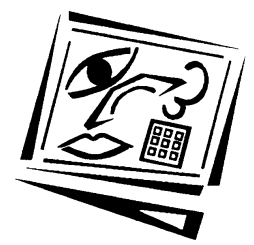

\title{
Cooperative or collaborative literacy practices: Mapping metadiscourse in a business students' wiki group project
}

\author{
Hesham Suleiman Alyousef \\ King Saud University \\ Michelle Yvette Picard \\ University of Adelaide
}

\begin{abstract}
Although wikis have been used successfully in collaborative learning in higher education, there is a lack of research investigating wikis in business module assessment tasks. Little research to date has been conducted on how wikis formatively develop international English as a second language (ESL) in business students' academic discourse. In this case study, students' use of a wiki in an assessment task in the Intermediate Financial Reporting (IFR) module is examined. This study is framed by Hyland and Tse (2004) and Hyland's $(2005,2010)$ models for the analysis of metadiscourse markers in IFR discourse. The findings of the interviews showed that although students collaborated and cooperated together to do the task, they favoured cooperative over collaborative learning. The linguistic analysis findings showed that the use of interpersonal metadiscourse features varied in the wiki discussion pages versus the report, indicating the students' awareness of their audience and the different genres, although the textual features of the wiki discussion pages resembled those of the report. The study is significant as it is the first to explore wikis' epistemological effects on Master of Commerce students' learning and it could potentially assist in the enhancement of wikis as a learning tool in profession-related courses, particularly those with high numbers of international, ESL students.
\end{abstract}

\section{Introduction}

The increasing numbers of students in higher education worldwide and the move towards student-centred and self-directed learning have created pressure on existing teaching resources and therefore created interest in web-based technologies. The term Web 2.0, or the read/write web, was coined by Tim O'Reilly (2005) to distinguish it from the earlier phase of the web, or the read/only web, which primarily focused on presenting information statically. The Web 2.0 revolution has impacted on education as noted by Luo (2009, p.32), "given students' heavy use of Web 2.0 technology, educators have started exploring their applications in teaching and learning". However, this impact has only recently been explored in sporadic case studies on the adoption of Web 2.0 technology in education (Bruns \& Humphreys, 2005; de Pedro et al., 2006; Pusey \& Meiselwitz, 2009; Luo, 2009), along with research on students' perceptions of wiki group work (Bruns \& Humphreys, 2005; de Pedro et al, 2006; Choy \& Ng, 2007; de Pedro, 2007; Robertson, 2008; Ramanau \& Geng, 2009; Ruth \& Houghton, 2009; Zorko, 2009; Judd, Kennedy \& Cropper, 2010; Mirk, Burkiewicz \& Komperda, 2010; Weaver, Viper, Latter \& McIntosh, 2010) and the effect of wikis on 
their writing skills in general (Rick et al., 2002; Hampel, Selke \& Vitt, 2005; Bruns \& Humphreys, 2005; Wheeler \& Wheeler, 2007; Miyazoe \& Anderson, 2010). However, no study on English as a second language (ESL) business students' wiki literacy practices, their experiences of formative and summative assessment, and the impact of this collaborative software on their use of academic discourse has been conducted to date. Collaborative learning in this context is used to mean the students doing the task together, whereas in cooperative learning they divide the task between themselves.

This paper focuses on the use of a wiki within the Blackboard learning management system in an assessment task in the Intermediate Financial Reporting (IFR) module. It aims to 1) study how students experience the use of this form of wiki in the IFR report writing assessment task; 2) analyse the textual and the interpersonal metadiscourse features in students' collaborative assignment writing, both in the wiki discussion pages and the report; 3) analyse the summative and the formative nature of the IFR assessment task, and compare the use of these features in wiki discussion pages and the report; and 4) analyse the collaborative nature of this assessment task.

\section{Methodology}

A case study research design was applied in this research, as case studies are a useful way of gaining detailed information on a particular educational event and its relationship to other events. The interaction of six ESL students who were studying Intermediate Financial Reporting was identified as an appropriate case study, since the largest number of international ESL students in Australia and elsewhere are clustered in business and commerce subjects. The Monthly Summary of International Student Enrolment (2010) reveals that "management and commerce was the top broad field of education in higher education, accounting for $47.1 \%$ of enrolments and $47.3 \%$ of commencements". Therefore, although the participants in this study cannot be claimed to be a representative sample, their combined efforts on the wiki provide a useful 'case' concerning the use of wikis by ESL students in an assessment task in a core business module. The participants in this case study were six first year Master of Commerce accounting students: one Saudi and five Chinese. To enroll in the program, the students needed to achieve 6 or more in the International English Language Testing System (IELTS) examinations, thus they have a "generally effective command of the language, despite some inaccuracies, inappropriacies and misunderstandings" (IELTS, 2011). A mixed-method approach was applied, including description of the assessment tasks, discourse analysis of the wiki discussion pages and the report, along with interviews. This case study is part of a larger investigation into the literacy and numeracy practices of international Master of Commerce students at an Australian university, which is supported by long-term ethnographic engagement with academics and students both on and off the campus.

The corpus consists of four wiki discussion pages (3596 words) and a report (2268 words) with a total word count of 5864 words. The wiki examined in this study is integrated into the University's learning management system (LMS), Blackboard. The tutor set a closed wiki site for each group. For anonymity, the students were assigned the pseudonyms Abdulrahman, Sun, Jiang, Edward, Tracy, and Lydia. Two reliability procedures were conducted to achieve reliability in coding of metadiscourse markers: iteratively cross-checking the meaning of the codes and revising the annotations with a fellow linguist. The discourse analysis of students' use of metadiscourse features as employed by Hyland and Tse (2004) and Hyland (2010) was used, because it had the 
potential to reveal the ways participants project themselves (Hyland, 2005) into the two different texts, the wiki discussion pages and the report.

Metadiscourse analysis reveals the way students use 1) the interactive markers to make their texts more cohesive, and 2) the interactional markers to signal their attitude towards both the propositional content and the audience of the text. Therefore an analysis of the interactional markers provides insight into the dialogic nature of the collaborative wiki. A semi-structured interview (Appendix 1) was conducted with one student, Abdulrahman, to gain a richer understanding of his experiences in the group assignment task that was completed online on a wiki over five weeks (April-May 2010). In addition, an interview with the tutor that aimed to gain an understanding how the groups were assessed in this work was conducted. Although experiences of only two participants cannot be claimed to be a representative sample, their reflections give some insights into the experiences of students and tutors.

\section{Metadiscourse}

The metadiscourse analysis which forms an integral part of this research is framed by Hyland and Tse (2004) and Hyland's (2005, 2010) models for the analysis of metadiscourse features in academic texts. Hyland (2010, p. 127) argues that through metadiscourse analysis we can "access the ways that writers and speakers take up positions and align themselves with their readers in a particular context". Thus this kind of analysis reveals the way students engage with different writing genres and communicate with each other. Hyland and Tse (2004) and Hyland's (2005, 2010) models assume two main categories for metadiscourse, interactive and interactional, that recognise the organisational and evaluative features of interaction respectively (Table 1). While interactive discourse refer to "the writer's management of information flow" to help guide the reader through the text, interactional markers refer to the writer's "explicit interventions to comment on and evaluate material" (Hyland \& Tse, 2004, p. 168 ) in order to involve the reader in the argument.

Interactive markers include transitions (to express semantic relations between clauses), frame markers (to refer to discourse acts, sequences, or text stages), endophoric markers (to refer to information in other parts of the text), evidential markers (to refer to the sourcing of information from other texts), and code glosses (for restatement of the ideational information). Interactional markers include hedges (to withhold writer's full commitment to proposition), boosters (to emphasise writer's certainty in proposition), attitude markers (to express writer's attitude to proposition), engagement markers (to explicitly refer to or build the relationship with reader), and self mentions (explicit reference to authors) (Table 1).

Following Hyland (1998), we have included parentheses and colons as instances of code glosses in the analysis, since much of the reformulation and exemplification is implemented through these visual markers. Hedges fall into two categories: low value subjective modalisation ("considering entities might be unable to cancel or transfer some liabilities") and low value modulated operators expressing choice ("might be not suitable"), possibility ("an entity could cancel or transfer an obligation", "the effect of possible new legislation is taken into consideration", and "possible obligation to be probable future outflows") and quality ("a change in legislation that would change or discharge the present obligation"). Engagement markers "explicitly address readers, either by selectively focusing their attention or by including them as participants in the 
text through second person pronouns, imperatives, question forms and asides" (Hyland, 2010, p. 129).

Table 1: Hyland and Tse (2004) and Hyland's (2010) models of metadiscourse

\begin{tabular}{|c|c|c|}
\hline Category & Function & Examples \\
\hline Interactive & Help to guide reader through text & Resources \\
\hline Transitions & $\begin{array}{l}\text { Express semantic relation between } \\
\text { main clauses }\end{array}$ & $\begin{array}{l}\text { In addition/thus/ but/ and/ therefore/ } \\
\text { however/ still }\end{array}$ \\
\hline $\begin{array}{l}\text { Frame } \\
\text { markers }\end{array}$ & $\begin{array}{l}\text { Refer to discourse acts, sequences, or } \\
\text { text stages }\end{array}$ & $\begin{array}{l}\text { First, second / finally/ to conclude / my } \\
\text { purpose here is / now, let's turn to }\end{array}$ \\
\hline $\begin{array}{l}\text { Endophoric } \\
\text { markers }\end{array}$ & $\begin{array}{l}\text { Refer to information in other parts of } \\
\text { the text }\end{array}$ & Noted above/ see figure/ in section \\
\hline $\begin{array}{l}\text { Evidential } \\
\text { markers }\end{array}$ & $\begin{array}{l}\text { Refer to sources of information from } \\
\text { other texts }\end{array}$ & According to $\mathrm{X} /(\mathrm{Y}, 1990) / \mathrm{Z}$ states \\
\hline Code glosses & $\begin{array}{l}\text { Signal the restatement of ideational } \\
\text { information }\end{array}$ & $\begin{array}{l}\text { Namely/ e.g. / such as / in other words/ } \\
\text { that is }\end{array}$ \\
\hline Interactional & Involve the reader in the argument & Resources \\
\hline Hedges & $\begin{array}{l}\text { Withhold writer's full commitment to } \\
\text { present propositional information } \\
\text { categorically }\end{array}$ & $\begin{array}{l}\text { Might/ perhaps/ possible/ about/ may/ } \\
\text { would / could / normally/ it appears } \\
\text { that / in many cases / I think }\end{array}$ \\
\hline Boosters & $\begin{array}{l}\text { Emphasise force or writer's certainty in } \\
\text { proposition }\end{array}$ & $\begin{array}{l}\text { In fact/ definitely/ highly/ it is clear } \\
\text { that / of course/ obvious }\end{array}$ \\
\hline $\begin{array}{l}\text { Attitude } \\
\text { markers }\end{array}$ & $\begin{array}{l}\text { Express writer's affective attitude to } \\
\text { propositions }\end{array}$ & $\begin{array}{l}\text { Unfortunately/ hopefully / I agree/ } \\
\text { surprisingly / honestly / appropriate/ } \\
\text { remarkable/ to tell the truth }\end{array}$ \\
\hline $\begin{array}{l}\text { Engagement } \\
\text { markers }\end{array}$ & $\begin{array}{l}\text { Explicitly refer to or build relationship } \\
\text { with reader (personal pronouns, } \\
\text { questions and commands) }\end{array}$ & Consider/ note that/ you can see that \\
\hline Self-mentions & Explicitly refer to authors & I/ me/ mine/ we/ our/ ours \\
\hline
\end{tabular}

Source: Hyland and Tse (2004) and Hyland (2010)

\section{Results of the study}

This section presents the aims of the assignment task, a description of the task, the group's postings on the wiki, the tutor's feedback, and the results of the interviews.

\section{Aims of the task}

The graduate attributes and the learning outcomes of the Master of Commerce Intermediate Financial Reporting module are stated in the Course Outline Reader. The learning outcome of this assessment task is to present coherent and persuasive arguments to an employer, client, auditor, or a regulator on important matters of accounting policy. This outcome is related to the following graduate attributes which are stated in the Course Outline Reader:

- Skills of a higher order in interpersonal understanding, teamwork and communication;

- A commitment to the highest standards of professional endeavour and the ability to take a leadership role in the community.

In order to develop students' communication skills, they are provided with a framework for debating and resolving accounting policy issues. This assignment is a problem based learning (PBL) task as it involves online discussion postings between 
the six group members which should lead, in the end, to co-authoring a report. The aims of this assignment are:

- Gain knowledge and communication skills

- Demonstrate innovative thinking

- Look at issues from different angles

- Ability to collaborate and work in a team

- Be ethical

- Have leadership skills

- Demonstrate research ability

Twu (2009, p. 18) states that "students generally need to have better understanding of how and why a wiki may support their learning". The tutor had indeed interwoven this meta-awareness of the medium into the task's scenario, in which each group of students imagine they are young employees who are required to provide their manager an informative report also show how a wiki can be used to enable communication, collaborative work practices, and knowledge sharing.

\section{Nature of the task}

The task is an enquiry based scenario. Upon reading this scenario, students are required to answer the following questions through the wiki's collaborative working feature, before writing the report:

- How is accounting policy made in Australia?

- What is the role of the International Accounting Standards Board (IASB). Why are the International Accounting Standards important?

- What are International Accounting Standards Exposure Drafts (EDs)?

- What are the current EDs and why are the accountants concerned about them?

These types of interrogatives seek explanations which foster students' capabilities to reason and to infer cause-effect relations. Students are required to engage in collaborative and individual knowledge building processes in order to present their report on a wiki which is allocated to a team of 4-6 students. In order to be comparable to a real world setting, students are informed that it does not matter if they do not know their team members in person. Notari (2006, p.131) points out that the major difficulty in setting wiki tasks is "to formulate a 'real life case' or problem in relation to the education goal and the learners' needs and level" - i.e. a scenario requiring explanation, disagreement, etc. In this assignment, the tutor attempts to make the scenario comparable to the workplace setting: e.g. a young graduate accountant assigned to submit a report to the boss about the recent releases of International Accounting Standards Exposure Drafts.

The tutor regulated and instructed students in this assignment task by commenting in the criteria for marking, not only on the content of the wiki pages, but also their research skills, communication skills, and innovativeness in using the wiki as a collaborative working tool. This is achieved through co-authoring, by making contributions and changes to each other's work on the report's wiki main page, before and after being engaged in discussions on additional wiki pages to share ideas, create, edit and discuss content. A collaborative written text consists of paragraph(s) that are convincing and coherent in terms of structure and content. Language choices are based 
on prior experience, social contexts, and references. Unlike traditional assignments, in this one the students are given complete freedom in regards to word limit, order of topics and format.

This freedom helps each group to build its own identity. The tutor states that students need to follow up quotations with explanations in their own words. They have to use the Harvard referencing system. The tutor asks students to complete an online form/survey posted before the assignment's due date, which aims to evaluate their team work experience and use of the wiki as a collaborative tool. This survey requires several short answers and it aims at meeting the learning needs of future students. Students unfamiliar with wikis can follow the link 'Wiki Testing Site' in the module's Blackboard site, which redirects them into a YouTube video. Rather than providing students with the traditional handouts, the tutor uses another form of Web 2.0 technology, an existing YouTube video clip to create a more visual learning experience.

\section{The group's postings on the wiki}

In order to complete the wiki task the team members designed one wiki page for the Report entitled "Report to the Boss" and four wiki pages for group Discussions under four major topics (Appendix 2) that are based on the task sheet requirements: 1) International Standards and accounting policy in Australia, 2) IASB and AASB, 3) current Exposure Drafts (EDs), and 4) accountants' concerns about the Eds (Table 2).

Four separate wiki pages were created for the topic-based discussions. While the task required the students to collaborate on the report writing process, in reality, they decided to designate 1-2 members for each wiki discussion page. They agreed, however, to allow contributions from other members if desired.

Table 2: The task sheet questions and the page titles created by the group in the wiki

\begin{tabular}{|c|c|c|c|}
\hline & Question & Web page number and title & Main contributors \\
\hline \multirow[t]{4}{*}{$\begin{array}{l}\text { Discussion } \\
\text { pages }\end{array}$} & $\begin{array}{l}\text { 1. How accounting policy is } \\
\text { made in Australia? }\end{array}$ & $\begin{array}{l}\text { 1. Why international standards } \\
\text { are important and how } \\
\text { accounting policy is made in } \\
\text { Australia? }\end{array}$ & $\begin{array}{l}\text { Abdulrahman and } \\
\text { Jiang }\end{array}$ \\
\hline & $\begin{array}{l}\text { 2. The role of the IASB: why the } \\
\text { International Standards are } \\
\text { important? }\end{array}$ & $\begin{array}{l}\text { 2. The relationship between } \\
\text { IASB and AASB, and their roles }\end{array}$ & Tracy and Sun \\
\hline & $\begin{array}{l}\text { 3. What EDs are and the part } \\
\text { they play in standard settings? }\end{array}$ & $\begin{array}{l}\text { 3. Current Exposure Drafts } \\
\text { (EDs) }\end{array}$ & Lydia and Edward \\
\hline & $\begin{array}{l}\text { 4. What the current EDs are and } \\
\text { what the accountants were } \\
\text { concerned about? }\end{array}$ & $\begin{array}{l}\text { 4. Why are the accountants } \\
\text { concerned about the exposure } \\
\text { drafts? }\end{array}$ & Abdulrahman \\
\hline The report & 5. (not applicable) & 5. Report to the Boss & $\begin{array}{l}\text { All the six } \\
\text { participants }\end{array}$ \\
\hline
\end{tabular}

This illustrates that, although collaborative tools are presumed to encourage collaborative behaviours, this is not necessarily the case as they also (or alternatively) support cooperative learning (Parker \& Chao, 2007). Collaborative learning means that the tasks are done together whereas cooperative learning means that the tasks are divided between learners. Only Lydia seemed to have collaborated with the other group members as she combined her accounting standards summary with Edward's (Appendix 2, Wiki Discussion Page 3): 
After reading Edward's post (thank for ur summary, its quite good :), i have combined her summary and my summary. Here it is:

1. IAS 19 Employee Benefits:

In summary, there are three main deficiencies in current IAS19:

1. Companies are not regulated under IAS19 to recognize their defined benefit plans in time. Such 'deferred recognition' makes the amount in financial statements misleading.

2. A united and standardized option for Companies to recognize gains and losses hasn't been set. This makes effects of defined benefit plans incomparable between companies.

3. Disclosures haven't put emphasis on the risks from defined benefit plans.

In addition, Lydia posted a table which includes both her contribution and a summary of what the other members have posted on the topic Exposure Drafts. As she states "Our members have already listed some EDs out :), but i will list them all in table anyway" (Appendix 2, Wiki Discussion Page 3). Students both collaborated and cooperated on these topics over a period of up to five weeks. In general, at the beginning the students faced difficulties finding the answers to this task. For example, Abdulrahman explains on Discussion Page 1 (Appendix 2), that he "can't really find the exact definition of why international accounting standards are important" since they ensure

\begin{abstract}
a fair and right analysis of the business performance and position, as well as allow comparison of businesses operating in different legal jurisdictions". All in all, International Accounting Standards ensure that businesses adopt similar rules/standards/policies in reporting the business activities, allowing analysis and comparison. (Appendix 2, Wiki Discussion Page 1)
\end{abstract}

Abdulrahman does not cite any references in his discussion. In response to the second question on this page "How is accounting policy made in Australia?" he lists and discusses eight procedures for making policy in Australia. He uses hyperlinks three times as an evidential marker to provide fact sheets about accounting standards. The six participants referred to sections, paragraphs, or appendices in the accounting policy standards per se as evidential markers: e.g. Framework (CF) project, IAS19, ED IAS 37, AASB 137, ED of IAS 37 Para.36C, AASB137 Para. 50, and ED of IAS 37 Appendix B13 (Appendix 2, Wiki Discussion Page 3). Lydia engages in true collaboration by combining her summary on IAS 19 Employee Benefits with Edward's and summarising the Exposure Drafts in a table which, as she states, "members have already listed some" (Appendix 2, lines 281-282). She tries to establish intersubjective shared understanding among her group members by co-authoring what has been written so far.

Abdulrahman's use of the interactive learning environment to negotiate conceptual meaning with his fellow members contradicts the widely held view that some second language students' learning rests solely on the transmission of theoretical knowledge. Instead, as the Vygotskian social constructivist approach acknowledges, "learning develops in the dynamic of spoken interaction" (Wake, 2006, p.6). The students fully utilised all the features of the wiki genre and used it to construct both formal and informal discourse. Emoticons are available in the wiki tools. However, because the task required the students to use the wiki to write and refine academic content iteratively, only 3 out of the 6 students chose to use this feature at the end of their postings to express their feelings or emotions. For example, Sun decided to use the emoticon (smile with a wink) and Abdulrahman, Jiang and Lydia used the emoticon 
(-) or its symbol :) (smile) to contextualise their discourse and create a sense of group interaction through humour. Luo (2009:39) suggested that some students use "Web 2.0 tools as social and entertainment "toys" and that this is reflected in the use of emoticons. However, in this study, students did not use emoticons as part of academic discourse, but rather preferred to use them to create close relationships with their group, which is appropriate to the discussion board genre.

\section{Tutor's general and group feedback}

The tutor provided a general feedback to all groups and group feedback. The general feedback includes the tutor's model answer to the question. This feedback helps students to evaluate their strengths and weaknesses in relation to the model answer, acting as a summative assessment since it occurred after students have submitted their report. The group feedback includes the tutor's assessment of each group. One of the aspects the tutor commented on was group participation. She notes in the group feedback that the statistics show one team member contributed only $1 \%$ of total lines saved. This lack of participation by this team member could be explained by the fact that this kind of technology lacks non-verbal cues and it is, therefore, sometimes hard to evaluate students' online, text based communications. Twu (2009) states some learners may be influenced by their cultural perceptions that regulate the way they interact in social relationships. As a result, they perceive the act of editing and modifying content created by others as a major offense. Therefore, these learners will be reluctant to participate in or initiate wiki activities.

Wheeler and Wheeler $(2007$, p.3) argue that some students will be reluctant to participate if they perceive "the strong probability that larger audiences exist beyond that of the conventional essay audience of 'one' and that they "need to adapt their writing styles, or open themselves up to scrutiny from a hidden audience". Twu (2009) suggests using strategies that promote harmony in social interaction by building a positive social learning environment. Twu also contends that instructors must convince their students that "editing" is not "correcting". It is the process through which ideas emerge and evolve clarification of meaning. Notari (2006, p.131) suggests developing a 'communication and comment culture' since "involving learners in making comments about the concepts of other learners helps construct personal knowledge and enhances meta-cognitive capacities". As the group members did not know each other beforehand, they need to find some way of establishing social ties. One way to break the ice could be to conduct a face to face meeting in week one. Tutors may also designate marks for those students who start early and engage in coauthoring.

The tutor comments on task achievement and specific strengths and weaknesses of the content. For example, she makes suggestions about content that should be added and asks the group to specify or clarify certain aspects. For example, the tutor commented on Abdulrahman's posting on Wiki Discussion Page 4:

include here who the AASB is other than it is a Government Agency. Who are the members? How many members?

Formative feedback like this has the potential to help the students to refine their final written product. However, in this case it was problematic as the students only received this feedback after the report had been handed in, which limited its usefulness and instead it acted as summative feedback. The tutor also provided feedback on the 
contributions of individual group members which was accessible to the whole group. For example, she commented on Abdulrahman's posting on Wiki Discussion Page 4:

On the "Why the accountants are concerned about the exposure drafts?" page

Abdulrahman has given a very good interpretation in his own words of why we in Australia should be concerned about EDs. This should have been in the report and if you wrote the whole report in this way, i.e. answers to the questions in your words rather than disjointed bits and pieces that you have found on the Web, you would have gotten a much better mark.

The tutor comments upon Abdulrahman's argumentation 'in his own words', which demonstrates an understanding of the topic Exposure Drafts and the relevant technical terms. She adds that he should have applied these skills to his final report. Unfortunately, as Abdulrahman did not receive this positive feedback prior to submitting his report, he did not automatically transfer the skills developed in the wiki to the report genre.

Although the task sheet implies that students will be evaluated both on the process (the wiki discussion pages) and the product (the wiki report's page), a final summative assessment was conducted after submission of the assignment. Thus Abdulrahman's learning outcomes were affected by the lack of formative assessment that could have occurred during the process. The tutor (personal communication, 5 October 2010) argued that she used formative assessment with groups that started early in order to encourage them. However, with later-starting groups, as in this case, only summative assessment was used at the end. She added that it was the first time for her to use a wiki in assessment tasks and she has decided to provide future students with immediate formative feedback.

\section{Results of the interviews}

In this section the results of the interviews with the tutor and one of the group members, Abdulrahman are discussed. The tutor states that she has been using a wiki in individual short assignments to provide students with formative feedback. For example, after students work out a tutorial activity, they are required to upload a scanned copy from their notebooks in order to receive the tutor's comments. Elgort, Smith and Toland (2008) suggest using scaffolding learning through the use of 'mini wiki-tasks' in order to prepare students for the main group assessment. The tutor contends that other groups have overcome the lack of the "Chat" feature within wiki by creating a wiki page entitled "Discussions". The tutor argues very few groups engaged online in co-authoring, because most were concerned with the schematic structure of the report. In addition, Abdulrahman's group only started to work on the wiki in the third week. To overcome this problem in the future and to motivate students, the tutor intends to designate marks for those who start at the very beginning.

Abdulrahman states that his group members faced a number of obstacles when working on the wiki to do the assessment task. Abdulrahman (personal communication, 22 July 2010) states that in addition to the email, his group members held three face to face meetings during the six-week assignment period, in weeks 2, 4 and 6. First, students started working on the wiki before meeting face to face. Abdulrahman noted that he had taken the initiative on week 2 and created web pages 1 and 4 when none of the other students had participated. This was potentially problematic, as they had not developed guidelines for working and 
miscommunication could have occurred. However, no complications were reported as the group designated 1-2 members for each discussion page on its first face to face meeting. However, the lack of a meeting did appear to impact on students taking an initiative to start early. The second problem related to meetings was that the group had to postpone or reschedule two of their three meetings because one or more of the members could not attend due to classes. In the kickoff meeting they had agreed that each discussion page would be investigated cooperatively by 1-2 members, though each member would be free to contribute in the other pages. Thus prolonged face to face meetings was one of the main reasons for delayed contributions, although the tutor clearly stated in the task sheet that, similarly to workplace situations, "it does not matter if students do not know their team members". She commented in the interview that some members in other groups started introducing themselves in the Discussion page they created. In week six, the group members met face to face in order to finalise the report, by deciding which bits and pieces to use in the report.

As most of the group was reluctant to engage in co-authoring, Edward was encouraged to follow the same path. As he puts it on Wiki Discussion Page 3 (Appendix 2, lines 329-333):

Since there are a lot of contributions in this page, I find it hard to edit or delete any of your contributions, therefore I would like to add what I understood when I read

Exposure Draft measurement of liabilities and Ed conceptual framework

Edward decided to add information rather than edit or delete any of the contributions when finding all his group members were engaged in this path. The tutor suggested in the task sheet a YouTube video tutorial for students not familiar with using wikis Abdulrahman appeared to have no difficulties using the wiki, he argues the video did not help him learn the key features of wiki. This suggests that in common with most Generation Y learners, he was familiar with the different forms of Web 2.0 technology such as social networking sites, blogs and video sharing sites - which have become part of his life.

The wiki format also has technical limitations which may affect the quality of the students' interactions. For example, since the wiki does not have a spell checker, either spontaneity may be affected when students stop and spell check or grammar check using a word processing program, or errors of expression may occur if they write directly on the wiki. Abdulrahman, however, argued that spontaneity was not affected at all when switching between the word processor and wiki pages.

Another more serious issue highlighted by Abdulrahman is equality of participation. Although, as noted above, the tasks were divided up at the first meeting, two of the students contributed for the first time only a few days before the assignment's deadline when realising that they would be assessed on their wiki contributions, as well as on the final hard copy of the report. He argues that may be they did not take this task seriously. Perhaps this is due to the fact that Web 2.0 tools are more often used as recreational "toys" than for academic purposes (Luo, 2009). Although the literature values the collaborative nature of wikis as educational tools (Bruns \& Humphreys, 2005; De Pedro et al., 2006; Pusey and Meiselwitz, 2009; Luo, 2009), they are not necessarily valued by all student participants. Abdulrahman felt that he would have spent less time doing the task by himself since he does not "have to wait for the students' feedback" (personal communication, 22 July 2010). Elgort, Smith and Toland (2008) argue that this problem could be encountered by preparing students for group 
assessment through the introduction of 'mini wiki-tasks'. Despite the issue of time, however, Abdulrahman was aware that the quality of the text was enhanced by the group collaborative work. He suggested, however, that each student should complete the whole task independently and then the group should meet and choose the best contributions. This indicates that although face to face interaction and collaboration are valued by this group, 5 out of the 6 participants resisted online collaboration by engaging in online discussions rather than co-authoring their colleagues' posts.

\section{Metadiscourse analysis}

The metadiscourse analysis of the wiki discussion pages and the report revealed the frequency of metadiscourse markers. Considering the text length in each genre, the metadiscourse analysis for the report (2268 words) showed a higher frequency of interactive markers (5.15 markers per 100 words) compared with interactional markers (3.2 markers per 100 words), while the frequency of these two categories in the wiki discussion pages (3596 words) was almost equal (5 markers per 100 words in each genre type). This is possibly because the wiki discussion postings occasionally digress from formal academic discourse into colloquialism and a more spoken-like pattern, to engage readers in the argument. This indicates that wiki discussion postings contained textual features that resemble the discourse of the report. Although the wiki discussion pages contained spoken-like interactional metadiscourse markers, they also combined features of written language. This movement between genres is evidenced in the dialogic question Abdulrahman initiates at the end of his contribution on Discussion Web Page 4 ("This is what I understood and hope getting feedback from you"). It emerges from the six-fold nature of his audience — the other 5 students who will respond to his interpretation and the tutor. Although wiki discussion postings are obviously written to be read (and assessed), Abdulrahman, Edward and Jiang initiate their postings with a salutation ('Hi guys' / 'Hi All'). Similarly, interjections (e.g. 'easier for you to see'/ 'do you think') are also used in order to engage participants in an argument.

The frequency of the interactive and interactional metadiscourse markers in the wiki discussion pages (the process) and the report's page (the product) (Appendix 2) are listed below.

Table 3: The frequency of interactive and interactional metadiscourse markers in the wiki discussion pages (3596 words) and the report (2268 words)

\begin{tabular}{|c|c|c|c|c|c|}
\hline \multirow{2}{*}{\multicolumn{2}{|c|}{ Categories }} & \multicolumn{2}{|c|}{ Discussion pages } & \multicolumn{2}{|c|}{ The report } \\
\hline & & Frequency & Percentage & Frequency & Percentage \\
\hline \multirow[t]{6}{*}{ Interactive } & Transitions & 76 & 42.5 & 49 & 41.9 \\
\hline & Evidential markers & 64 & 35.8 & 37 & 31.6 \\
\hline & Code glosses & 24 & 13.4 & 14 & 12.0 \\
\hline & Frame markers & 4 & 2.2 & 14 & 12.0 \\
\hline & Endophoric markers & 11 & 6.1 & 3 & 2.5 \\
\hline & Total interactive & 179 & 100 & 117 & 100 \\
\hline \multirow[t]{6}{*}{ Interactional } & Engagement markers & 49 & 27.5 & 6 & 8.3 \\
\hline & Self-mentions & 46 & 25.8 & 1 & 1.4 \\
\hline & Hedges & 52 & 29.2 & 37 & 51.4 \\
\hline & Attitude markers & 30 & 16.9 & 28 & 38.9 \\
\hline & Boosters & 1 & 0.6 & 0 & 0.0 \\
\hline & Total interactional & 178 & 100 & 72 & 100 \\
\hline
\end{tabular}


The metadiscourse analysis of the interactive markers revealed that transitions, evidential markers, code glosses, and endophoric markers ranked higher in the wiki discussion pages compared with the final report. Notably, the use of frame markers was about five times higher in the report than in the discussion pages.

The analysis of interactional metadiscourse markers revealed that engagement markers and self-mentions ranked higher in wiki discussion pages $(27.5 \%$ and $25.8 \%$ respectively) than in the final report $(8.3 \%$ and $1.4 \%$ respectively), while hedges and attitude markers ranked higher in the report, $51.4 \%$ and $38.9 \%$ respectively. Hedges were the most frequently used interactional markers in the report (51.4\%) and in the wiki discussion pages $(29.2 \%)$.

The use of engagement markers in the wiki discussion pages was three times higher than in the report. While over $34 \%$ of the interactional devices in the wiki discussion pages were self-mentions (I/my/we/our) and 'reader pronouns (you/your), the report almost lacked these resources, reflecting the typical formal academic discourse valued by most tutors. Students use 'must', 'should' and 'will' to strongly emphasise their point of view. They also use 'may', 'could, 'would' and 'possible' to explicitly express their arguments to the readers/tutor with due caution. Self-mentions include verbs expressing mental processes (think, see, focus, suggest), relational processes (have, be), behavioural processes (suggest, found) and material processes (post, summarise, read) as in the following examples (Appendix 2):
138 This is my summary.
190-192 I think it might be easier for you to see what I posted.
195-196 I haven't found the exact instruction in assignment.
204-206 In my opinion, once the EDs published by the IASB are commented and modified, they will become the final form.
312-314 To make our job easy and clear, I suggest we focu [sic] on 4 first.
391-393 I did not find a certain answer for this issue. However, according to my understanding, I come up with the following Justification.

The wiki discussion pages combine features appropriate to an expository essay with those usual for email discussion. The hybrid genre students produce is appropriate for this occasion. The writers establish rapport with the readers and show consideration for their fellow members through the use of the first person plural pronouns we, our, and $u s$, as in the following (Appendix 2):
194-195 I am not quite sure that is it a must for $u s$ to list out the differences
bewteen [sic] AASBs and IASs
196-197 Let $u s$ find this differences
198-200 This question raised in the instruction that we haven't even talked about
208-210 So all our work, like finding out these differences, is to forecast in what way the current EDs will affect AASB

There are 15 instances where writers use the second person 'you' and 'your' to seek members' confirmation of a viewpoint, as in "You are right. It is worthy [sic] paying attention to that point", or to ask a member for his/her opinion as in "What do you think?" Students use commands and questions to argue or present propositional content related to accounting standards, such as in "why international accounting standards are important" and "identify technical issues". Finally, the report lacks 
instances of boosters, while they occur only once in the wiki discussion pages ("Hence, it will centainly [sic] have great impacts on the AASB").

\section{Discussion of the findings}

The description of students' postings on the wiki and the findings from the interviews showed that most of students favoured cooperative learning over collaborative. This finding is in line with a number of studies (Krebs \& Ludwig, 2009; Judd, Kennedy \& Cropper, 2010; Weaver et al., 2010). For example, Weaver et al. (2010) found that few students engage in collaboration as "most groups delegated tasks to individuals within the group". Krebs and Ludwig (2009) also found that students divided the work into different areas and dealt with their topics on their own, instead of collaboratively developing and editing content in the wiki. Since the tutor cannot track contributions on the Discussion Board, students posted their comments on the wiki discussion pages and created a page for the report entitled "Report to the Boss" (Appendix 2, Wiki Report). It seems that students prefer cooperative learning in order to cope with the high learning demands in tertiary studies. It can be argued that most students' collaborations were not true since they were not engaged in co-authoring but rather providing feedback to each other. Only Lydia's contribution is collaborative as she combined her accounting standards summary with Edward's, in addition to using a table to add her contribution and at the same time summarised what the other members had posted on the topic Exposure Drafts. This findings supports Judd, Kennedy and Cropper's (2010, p. 351) assertion that despite the fact that wikis encourage collaboration "using 'collaborative' technologies, does not guarantee students will work together in a cohesive way."

The students' way of working was perhaps due to the nature of the task. Since the students were rewarded on the number and quality of posts in the wiki, not how well they collaborated or worked together, the task itself seems to be cooperative rather than collaborative. De Pedro et al (2006) argue that the asynchronous nature of such collaboration has been viewed as promoting cooperation rather than competition amongst students. Each student in this study negotiated the content and structure of the wiki with his/her peers. The use of a wiki thus contributed to the group members' communication and knowledge sharing, thereby helping to improve the quality of their writing, as Abdulrahman stated. Most of the aims of the task seem to have been fulfilled, such as working in a team, gaining knowledge and communication skills, collaborating (as seen by Lydia's collaboration), demonstrating research abilities, demonstrating innovative thinking, and examining issues from different angles (when the group members negotiated with their peers).

The finding that the use of a wiki did not enable collaboration between most of the group members cannot be generalisable, as the tutor argues that few groups engaged online in co-authoring. In addition this group's collaboration during the face to face meeting when they decided which bits and pieces to take was based on the contributions and the peer feedback posted on the wiki Discussion pages. Abdulrahman's worries about the equality of participation can be tackled through the tutor's development of early intervention strategies to encourage the engagement of reluctant students (Weaver et al, 2010).

Though feedback helps students in knowing their points of strengths and their weaknesses, the summative feedback students received is likely to be of limited benefit 
as their contributions were evaluated at the end of the semester. While students in this study were informed that their assessment would depend not only on the product (the report), but also the collaborative process represented by their contribution, most students in the case study were reluctant to engage in altruistic acts by editing each other's pages, because they were probably concerned that such acts would either be not rewarded or their contribution would not be better than the deleted one.

Online synchronous meetings were not conducted in this study, perhaps because the students had three face to face meetings, or because the learning management system (LMS) used in this study did not have a "Chat" service. Prolonged contributions which were mainly caused by the delaying of the face to face meeting between the group members could be tackled by creating a separate wiki page for asynchronous discussions. Postponed meetings were amongst the difficulties found in a study by de Pedro et al (2006), which also included the tutor's motivation and previous training. Although the wiki used in this study had no spell checker, Generation Y learners are used to switching between different software, i.e. the word processor and the wiki.

Finally, the linguistic metadiscourse analysis showed that the wiki discussion pages contained spoken-like interactional metadiscourse markers (e.g. self mentions, reader pronouns and interjections) and also combined features of written language. The use of interactive markers was almost equal in both the discussion pages and the report. On the other hand, the use of frame markers in the report was about five times higher than in the discussion pages, reflecting students' awareness of the academic nature of reports and the differences between genres. However, most of the evidential markers used in the wiki discussion pages were hyperlinks, one of the features of Web 2.0 technologies. This feature is becoming widely used in reports. In contrast, the use of endophoric markers in the wiki discussion pages was higher than in the report. The findings for interactional metadiscourse markers revealed that wiki discussion pages contained almost double the amount of these resources than the report, indicating the semi-dialogic nature of the collaborative wiki. Since students used the wiki discussion pages as a Discussion Board, self-mentions were very high $(25.8 \%)$, compared to $1.4 \%$ in the report (Table 3). This explains why the discourse in some parts of these pages is informal, personal, and emotive. In contrast, hedges were higher in the report $(51.4 \%)$ than in the wiki discussion pages (29.2\%) (Table 3). This supports Hyland and Tse's (2004) finding that hedges constituted the highest frequency of occurrence amongst other interactional markers in academic writing.

Only the wiki discussion pages contained personal pronouns that engaged the readers and, thereby, made the text more personal, interesting, and easy to follow. The discourse analysis showed that students used formal academic language in their report. However, in the discussion pages, formal-like academic language paralleled the spoken-like features.

The pedagogical implications for the use of the wiki based learning in a tertiary education environment are drawn from the findings and the literature. Therefore the following is necessary:

- Designating marks for those students who start early and engage in editing the implausible comments;

- Introducing 'mini wiki-tasks' (Elgort, Smith \& Toland, 2008) that prepare students for group assessment; 
- Encouraging students to create a separate wiki page for asynchronous Discussions in order to tackle delayed face to face meetings between the group members;

- Giving formative assessment equal weight with summative assessment;

- Encouraging late starters to participate in or initiate wiki activities;

- Assisting ESL students in using Microsoft Word spell and grammar checkers; and

- Giving students immediate feedback.

\section{Conclusion}

In this paper we have investigated how Master of Commerce IFR ESL students experienced the use of the wiki, investigated the aim and nature of this assessment task, and analysed the metdiscourse markers of the wiki discussion pages and the report. The wiki was used for both cooperative and collaborative teamwork. However, although some collaboration took place during the third face to face meeting when the group members decided which bits and pieces to take, most of the collaborations did not occur online. As the tutor argues, very few groups engaged online in co-authoring. With the exception of Lydia, online teamwork mainly involved cooperative practice. It can be argued that students' engagement in this practice could resemble workplace activities since employees usually divide up tasks, conduct online discussions, report back to the manager, and then refine the work. Above all, as Duffy (2008) states, "as more organizations adopt the wiki for internal and external collaboration and information, work with wikis at the tertiary level builds crucial skills for the workplace". This is pertinent for ESL business students who have to operate in an English work environment.

The analysis of interactive and interactional metadiscourse markers revealed, respectively, the way students anticipate readers' need to follow an argument, and to participate in a dialogue. The discourse analysis showed that students used formal academic language in their report. However, in the discussion pages formal-like academic language paralleled the spoken-like features. The use of interactive metadiscourse markers was almost equal in both the discussion pages and the report. It is clear from students' use of the various metadiscourse markers that they have a good grasp of the various features of different genres. This indicates that the wiki task facilitated ESL business students' awareness of their audience in each genre type.

The results of the interviews illustrate the importance of studying the effect of the lack of a spell checker in wikis on ESL students' spontaneity. Further research comparing the use of wikis by ESL learners with local native speakers would be useful to ascertain whether this form of communication and co-authoring has similar effects on these different cohorts. Further research is also needed to investigate the causes of and remedies for low levels of collaboration amongst students.

\section{Acknowledgments}

We would like to thank the two anonymous reviewers for their constructive feedback. We sincerely thank Jessica Scott for her member-checking the MD analysis. We also thank Dr Peter Mickan for his invaluable support and encouraging comments on an earlier draft. 


\section{Appendix}

Appendix 1: The semi-structured interview and Appendix 2: Metadiscourse analysis of the wiki discussion pages and the report are contained in the accompanying file 'alyousefappendix.pdf'. URL http: / / www.ascilite.org.au/ ajet/ ajet27/ alyousef-appendix.pdf

\section{References}

Bruns, A. \& Humphreys, S. (2005). Wikis in teaching and assessment: The M/Cyclopedia project. In WikiSym '05, Proceedings of the 2005 international symposium on Wikis, pp. 25-32. New York: ACM. http:/ / portal.acm.org/ citation.cfm?id=1104976

Choy, S. O. \& Ng, K. C. (2007). Implementing wiki software for supplementing online learning. Australasian Journal of Educational Technology, 23(2), 209-226.

http: / / www.ascilite.org.au/ajet/ajet23/choy.html

de Pedro, X. (2007). New method using wikis and forums to evaluate individual contributions in cooperative work while promoting experiential learning: results from preliminary experience. In WikiSym'07. Proceedings of the 2007 international symposium on Wikis, Montreal, Quebec, Canada, 21-23 October. http:/ / www.wikisym.org/ws2007/_publish/ dePetro_WikiSym2007_ContributionsInCooperativeWork.pdf

De Pedro, X., Rieradevall, M., López, P., Sant, D., Piñol, J., Núñez, L., et al. (2006). Writing documents collaboratively in higher education using traditional vs. wiki methodology (I): Qualitative results from a 2-year project study. Paper presented at the International Congress of University Teaching and Innovation, Barcelona, 5-7 July. http: / / uniwiki.ourproject.org/tiki-index.php

Duffy, P. (2008). Engaging the YouTube Google-eyed generation: Strategies for using Web 2.0 in teaching and learning. The Electronic Journal of e-Learning, 6(2), 119-130. http: / / www.ejel.org/issue / download.html?idArticle $=64$

Elgort, I., Smith, A. G. \& Toland, J. (2008). Is wiki an effective platform for group course work? Australasian Journal of Educational Technology, 24(2), 195-210. http: / / www.ascilite.org.au/ajet/ajet24/elgort.html

Hampel, T., Selke, H. \& Vitt, S. (2005). Deployment of simple user-centered collaborative technologies in educational institutions-experiences and requirements. Paper presented at the 14th IEEE International Workshops on Enabling Technologies: Infrastructure for Collaborative Enterprise (WETICE'05), Linköping, Sweden, 207-212. http:/ / dx.doi.org/ 10.1109/WETICE.2005.29

Hyland, K. (1998). Persuasion and context: The pragmatics of academic metadiscourse. Journal of Pragmatics, 30(4), 437-455. http:/ / dx.doi.org/10.1016/S0378-2166(98)00009-5

Hyland, K. (2005). Metadiscourse: Exploring interaction in writing. Continuum, London.

Hyland, K. (2010). Metadiscourse: Mapping interactions in academic writing. Nordic Journal of English Studies, Special Issue: Metadiscourse, 9(2), 125-143. http: / / ojs.ub.gu.se/ojs/index.php/ njes/article/view/417/ 405

Hyland, K. \& Tse, P. (2004). Metadiscourses in academic writing: A reappraisal. Applied Linguistics, 25(2), 156-177. http: / / dx.doi.org/10.1093/applin/25.2.156

IELTS (2011). Institutions - IELTS band scores. [viewed 21 May 2011] http: / / www.ielts.org/institutions / test_format_and_results/ielts_band_scores.aspx 
Judd, T., Kennedy, G. \& Cropper, S. (2010). Using wikis for collaborative learning: Assessing collaboration through contribution. Australasian Journal of Educational Technology, 26(3), 341354. http:/ / www.ascilite.org.au/ajet/ajet26/judd.html

Krebs, M. \& Ludwig, M. (2009). Math learning with wikis. Ninth International Conference on Technology in Mathematics Teaching (ICTMT 9), 6-9 July, Metz, France. http: / / www.ictmt9.org/files/contributors / eefccc520efe19e7cf5e9a1529f133f1/SP_krebs.pdf

Luo, L. (2009). Web 2.0 integration in information literacy instruction: An overview. Journal of Academic Librarianship, 36(1), 32-40. http: / / dx.doi.org/10.1016/j.acalib.2009.11.004

Mirk, S. M., Burkiewicz, J. S. \& Komperda, K. E. (2010). Student perception of a wiki in a pharmacy elective course. Currents in Pharmacy Teaching and Learning, 2(2), $72-78$. http:/ / dx.doi.org/10.1016/j.cptl.2010.01.002

Miyazoe, T. \& Anderson, T. (2010). Learning outcomes and students' perceptions of online writing: Simultaneous implementation of a forum, blog, and wiki in an EFL blended learning setting. System, 38(2), 185-199. http: / / dx.doi.org/10.1016/j.system.2010.03.006

Monthly summary of international student enrolment data (2010). Australian Education International. [viewed 21 May 2011] http: / / aei.gov.au/AEI/Statistics / StudentEnrolmentAndVisaStatistics / Default.htm

Notari, M. (2006). How to use a wiki in education: 'Wiki based effective constructive learning'. In WikiSym'06. Proceedings of the 2006 international Symposium on Wikis, 21-23 August, Odense, Denmark. http:// www.wikisym.org/ws2006/proceedings/p131.pdf

O'Reilly, T. (2005). What is Web 2.0: Design patterns and business models for the next generation of software. O'Reilly Media. http:/ / oreilly.com/ web2 / archive/ what-is-web20.html

Parker, K. R. \& Chao, J. T. (2007). Wiki as a teaching tool. Interdisciplinary Journal of Knowledge and Learning Objects, 3, 57-72. http: / / www.ijklo.org/Volume3/IJKLOv3p057072Parker284.pdf

Pusey, P. \& Meiselwitz, G. (2009). Heuristics for implementation of wiki technology in higher education learning. Online Communities and Social Computing. Lecture Notes in Computer Science, Volume 5621, 507-514. DOI: 10.1007/978-3-642-02774-1_55

Ramanau, R. \& Geng, F. (2009). Researching the use of Wiki's to facilitate group work. Procedia Social and Behavioral Sciences, 1(1), 2620-2626. http:/ / oro.open.ac.uk/id/ eprint/ 27433

Rick, J., Guzdial, M., Holloway-Attaway, K. C. L. \& Walker, B. (2002). Collaborative learning at low cost: CoWeb use in English composition. Paper presented at the Proceedings of Computer Support for Collaborative Learning Conference, Boulder, CO, USA.

Robertson, I. (2008). Learners' attitudes to wiki technology in problem based, blended learning for vocational teacher education. Australasian Journal of Educational Technology, 24(4), 425-441. http:/ / www.ascilite.org.au/ajet/ajet24/ robertson.html

Ruth, A. \& Houghton, L. (2009). The wiki way of learning. Australasian Journal of Educational Technology, 25(2), 135-152. http:/ / www.ascilite.org.au/ajet/ ajet25/ruth.html

Twu, H.-L. (2009). Effective wiki strategies to support high-context culture learners. TechTrends, 53(5), 16-21. 
Wake, B. J. (2006). Dialogic learning in tutorial talk: A case study of semiotic mediation as a learning resource for second language international students. Unpublished $\mathrm{PhD}$ thesis, The University of Adelaide. http: / / hdl.handle.net/2440/40128

Weaver, D., Viper, S., Latter, J. \& McIntosh, P. C. (2010). Off campus students' experiences collaborating online, using wikis. Australasian Journal of Educational Technology, 26(6), 847-60. http: / / www.ascilite.org.au/ajet/ajet26/weaver.html

Wheeler, S. \& Wheeler, D. (2007). Evaluating Wiki as a tool to promote quality academic writing skills. Paper presented at the Conference ICL2007, 26-28 September, Villach, Austria. http: / / telearn.noe-kaleidoscope.org/warehouse/158_Final_Paper_(001680v1).pdf

Zorko, V. (2009). Factors affecting the way students collaborate in a wiki for English language learning. Australasian Journal of Educational Technology, 25(5), 645-665. http: / / www.ascilite.org.au/ajet/ajet25/zorko.html

Authors: Hesham Suleiman Alyousef is a lecturer in the Department of English and Literature at King Saud University in Riyadh, Saudi Arabia. He is completing his PhD dissertation on the literacy and numeracy practices of Master of Commerce students from the perspectives of systemic functional linguistics and academic literacies. He completed his MA in Applied Linguistics in 2007 at King Saud University. His research interests include systemic functional linguistics, academic literacies, metadiscourse, multimodal discourse analysis and the use of Web 2.0 technology in higher education. Email: hesham@ksu.edu.sa

Dr Michelle Yvette Picard is a senior lecturer and Director of Researcher Education and Development at Adelaide Graduate Centre, the University of Adelaide. Her research interests include academic language and learning, language and culture, postgraduate supervision, issues in higher education, academic literacies and elearning. Email: michelle.picard@adelaide.edu.au

Please cite as: Alyousef, H. S. \& Picard, M. Y. (2011). Cooperative or collaborative literacy practices: Mapping metadiscourse in a business students' wiki group project. Australasian Journal of Educational Technology, 27(3), 463-480.

http: / / www.ascilite.org.au/ajet/ajet27/alyousef.html 